\title{
Pesan Nonverbal dalam Komunikasi Politik Wahidin Halim Sebagai Calon Gubernur Banten pada Pilkada Banten 2017
}

\author{
Fitria Santi \\ Prodi IImu Komunikasi FISIP Universitas Muhammadiyah Tangerang \\ Email: fitria78santi@gmail.com
}

\begin{abstract}
ABSTRAK
Penelitian ini bertujuan untuk mengetahui pesan nonverbal dalam komunikasi politik Wahidin Halim pada Pilkada Banten 2017, dan difokuskan hanya kepada pesan kinesik, proksemik, artifaktual, dan paralingustik. Pendekatan yang digunakan dalam penelitian ini adalah kualitatif dengan metode deskriptif. Teknik pengumpulan data menggunakan wawancara mendalam dan observasi nonpartisipan sebagai sumber data primer, dengan studi pustaka dan dokumentasi sebagai sumber sekunder. Hasil penelitian menunjukkan bahwa Wahidin Halim selalu tersenyum (pesan fasial) ketika sedang berhadapan dengan masyarakat Banten, sementara gerak olah tangannya (hand gesture) lebih sering terlihat mengangkat tangan dengan jari terbuka. Ketika berada di tengah masyarakat, jarak yang yang terbangun antara Wahidin Halim dengan masyarakat Banten tergolong jarak intim dan personal, sementara penampilan (pesan artifaktual) yang merupakan ciri khasnya ialah baju koko putih, celana hitam, dan peci hitam. Adapun dalam hal kecepatan bicara tergolong cepat, dengan intonasi suara bersemangat serta gaya komunikasi yang ceplas-ceplos dan humoris.
\end{abstract}

Kata Kunci: Komunikasi politik, pesan nonverbal, Pilkada Banten 2017, Wahidin Halim

\begin{abstract}
This study aims to find out various nonverbal messages in Wahidin Halim's political communication in 2017 Banten elections, and focused only on the message of kinesik, proxemik, artifactual, and paralingustik. The approach used in this study is qualitative with descriptive method. The data collection techniques used in-depth interview and nonparticipant observation as primary data sources, with literature study and documentation as secondary sources. The results of this study showed that Wahidin Halim always smiled (facial message) when he was meeting the people of Banten, while the hand gesture was more often seen raising his hand with his fingers open. During the campaign, the distance between Wahidin Halim and the people of Banten was classified as intimate and personal. Meanwhile, the appearance (artifactual message) which is his trademark is white koko, black pants and peci hitam. As for the speed of speaking, Wahidin Halim is quite fast, enthusiasm in tone, and the communication style is ceplas-ceplos and humorous.
\end{abstract}

Keywords: Political communication, nonverbal message, Banten Elections 2017, Wahidin Halim

\section{PENDAHULUAN}

Dalam kampanye politik, setiap kandidat perlu melakukan upaya persuasif guna meyakinkan masyarakat agar memilihnya, baik melalui pesan verbal (berupa suara atau pesan tertulis) ataupun melalui bahasa tubuh (nonverbal). Sebuah studi yang dilakukan Albert Mehrabian (dalam Cangara, 2009) menyatakan bahwa tingkat kepercayaan orang hanya 7\% berasal dari bahasa verbal, 38\% dari vokal suara dan 55\% dari ekspresi muka. Mehrabian

Citation : Santi, Fitria. (2018). “Pesan Nonverbal dalam Komunikasi Politik Wahidin Halim Sebagai Calon Gubernur Banten pada Pilkada Banten 2017". Nyimak Journal of Communication, 2(2): 131-149. 
pun menambahkan bahwa jika terjadi pertentangan di antara apa yang diucapkan seseorang dengan perbuatannya, maka orang cenderung mempercayai hal-hal yang bersifat nonverbal.

Berdasarkan studi yang dilakukan oleh Mehrabian tersebut bisa dikatakan bahwa pesan nonverbal memiliki peran signifikan dalam proses komunikasi politik, khususnya ketika seorang calon sedang menemui masyarakat yang menjadi konstituen politiknya. Hal seperti ini tentunya dialami semua kandidat politik yang menjadi peserta kampanye, tidak terkecuali pasangan Wahidin Halim-Andika Hazrumy pada Pilkada Banten 2017. Bahkan, keduanya dihadapkan dengan latar belakang masyarakat yang dikenal sebagai masyarakat agamis (religus) (Humaeni, 2015).

Selain dihadapkan dengan kondisi masyakarat yang agamis, Wahidin Halim pun dihadapkan dengan terpaan isu dinasti politik, sebuah isu yang sebenarnya telah muncul ke permukaan jauh haru sebelumnya dan menjadi perhatian berbagai kalangan di Banten (Agustino, 2010, 2011; Hamid, 2014; Kusumaningtyas, 2017; Mariana \& Husin, 2017; Nashrudin, 2017; Sutisna, 2015, 2017; Witantra \& Nesia, 2000). Isu lainnya yang juga tak kalah hebatnya, adalah isu korupsi. Isu ini pun sebenarnya sudah mengemuka jauh sebelum pelaksanaan Pilkada Banten 2017 (Christiawan, 2016; Fauzanafi, 2016; Hakim (et al.) 2017; Nisa, Dwisetia \& Firmansyah, 2017; Saragintan \& Hidayat, 2016; Sitompul, 2014).

Dari berbagai tantangan tersebut, pada akhirnya Wahidin Halim bersama dengan Andika Hazrumy berhasil memenangkan Pilkada Banten meskipun kemenangan mereka hanya terpaut tipis: pasangan Wahidin Halim-Andika Hazrumy meraih 2.411.213 suara, sementara pasangan Rano Karno-Embay Mulya Syarif meraih 2.321.323 suara. Di balik kemenangan tersebut tentunya peran komunikasi politik yang dilakukan Wahidin Halim tidak mungkin diabaikan begitu saja baik dalam bentuk pesan verbal maupun nonverbal.

Pada konteks Pilkada Banten 2017, peran pesan nonverbal yang digunakan oleh Wahidin Halim mempunyai peran signifikan guna mendukung pesan-pesan verbal yang disampaikan (baik lisan maupun tertulis) kepada masyarakat Banten, baik menyangkut visi-misi, program kerja maupun untuk melawan propaganda yang dilancarkan lawan politiknya: Rano KarnoEmbay Mulya Syarief.

Selain itu, lewat pesan-pesan nonverbal, masyarakat Banten pun dapat mengenal lebih dekat "calon pemimpin" mereka: religius atau tidak (salah satunya melalui pesan artifaktual/ penampilan), tegas atau tidak (lewat pesan paralinguistik yang berhubungan dengan pengucapan pesan nonverbal), dekat dengan rakyatnya atau tidak (melalui pesan proksemik dan sentuhan), murah senyum/ramah atau tidak (melalui pesan kinesik), dan lain sebagainya. 
Karena itu, politisi atau pemimpin politik yang dapat memanfaatkan komunikasi nonverbal dan menyelaraskan dengan pesan-pesan verbal yang hendak disampaikannya, tidak menutup kemungkinan akan mendapat simpati dari masyarakat (dan pada akhirnya masyarakat akan menjatuhkan pilihan politik mereka kepadanya).

Sementara itu, ada berbagai penelitian tentang komunikasi atau pesan nonverbal yang relevan dengan penelitian ini, seperti penelitian yang dilakukan oleh Megasari N. Fatanti dan I Wayan Suyadnya (2017), Belinda Harefa (2015), Khaerul Azmi (2017), S. Bekti Istiyanto (2010) dan Bayu Nitin Pratiwi (2017). Dalam kelima penelitian tersebut, hanya penelitian yang dilakukan oleh Khaerul Azmi (2017) yang mempunyai kesamaan subjek penelitian dengan penelitian ini, yaitu Wahidin Halim. Selain berbeda dalam hal penggunaan teori, penelitian tersebut juga hanya dibatasi pada pengelolaan kesan yang dilakukan Wahidin Halim melalui media Facebook dan Twitter.

\section{KERANGKA TEORI}

\section{Komunikasi Politik}

Komunikasi politik didefinisikan Meadow (dalam Nimmo, 2004) sebagai: "any exchange of symbol or message that to a significant extent have been shaped by or have consequences for political systems." Meadow memberikan tekanan simbol-simbol atau pesan yang ingin disampaikan secara signifikan dibentuk atau mempunyai konsekuensi terhadap sistem politik.

Dalam Introduction to Political Communication (2003), ahli komunikasi politik Brian McNair mendefinisikan komunikasi politik sebagai: "...pure discussion about the allocation of public resources (revenue), official authority (who is given the power to make reward or punishes." Artinya, komunikasi politik menurut McNair adalah murni membicarakan mengenai alokasi sumberdaya publik yang mempunyai nilai, baik nilai kekuasaan maupun nilai ekonomi, para petugas yang mempunyai kewenangan memberi kekuasaan dan keputusan dalam pembuatan UU atau aturan, baik itu legislatif maupun eksekutif, serta sanksi-sanksi baik dalam bentuk hadiah maupun denda (McNair, 2003).

Sementara itu, ahli ilmu politik seperti Almond dan Powell, justru menempatkan komunikasi politik sebagai fungsi politik, bersamaan dengan fungsi artikulasi, agregasi, sosialisasi, dan rekrutmen yang ada dalam suatu sistem politik tertentu. Menurut kedua pakar tersebut, komunikasi politik ialah prasyarat yang diperlukan bagi berlangsungnya fungsifungsi yang lain (dalam Arifin, 2011).

Cangara (2016) mengartikan komunikasi politik sebagai proses komunikasi dan memiliki implikasi terhadap aktivitas politik. Faktor ini pulalah yang membedakan komunikasi politik dengan berbagai disiplin komunikasi lainnya, misalnya komunikasi pembangunan, komunikasi 
pendidikan, komunikasi antarbudaya, dan lain sebagainya. Perbedaan itu terletak pada "isi pesan". Artinya, komunikasi politik mempunyai pesan bermuatan politik, sementara komunikasi pendidikan mempunyai pesan yang bermuatan masalah-masalah pendidikan. Dengan demikian, perbedaannya adalah terletak pada sifat atau isi pesan.

Untuk menghindari komunikasi politik tidak hanya berbicara tentang kekuasaan, Doris Garber menyatakan dalam tulisannya Political Language (1981) jika komunikasi politik tak hanya retorika, tetapi juga mencakup simbol-simbol bahasa, seperti bahasa tubuh dan tindakan-tindakan politik seperti boikot, protes, unjuk rasa. Dengan demikian, pengertian komunikasi politik dapat dirumuskan sebagai proses pengoperan lambang-lambang atau simbol-simbol komunikasi yang berisi pesan-pesan politik dari seseorang atau kelompok kepada orang lain, dengan tujuan membuka wawasan atau cara berpikir, serta memengaruhi tingkah laku atau perilaku khalayak yang menjadi target politik.

Menurut Arifin (2011) perbedaan pengertian tersebut disebabkan karena baik komunikasi maupun politik merupakan sebuah fenomena yang "serbahadir" (ubiquitos). Artinya, komunikasi dan politik berada di mana pun dan kapan pun juga; setiap orang berkomunikasi dalam bentuk berpikir, berbicara, menulis, dan bertindak. Karena itulah, setiap tindakan politik selalu mempunyai arti/makna politik (everything is political). Hal ini juga sejalan dengan pandangan Aristoteles yang menyatakan bahwa secara alamiah manusia merupakan makhluk yang berpolitik (zoon politicon) sehingga politik menjadi hakikat keberadaan manusia dalam kehidupan bermasyarakat.

\section{Bentuk-Bentuk Komunikasi Politik}

Terdapat beberapa bentuk komunikasi politik yang dilakukan oleh komunikator politik untuk mencapai tujuannya (Hikmat, 2010).

a. Retorika

Berasal dari bahasa Yunani (rhetorica), yang artinya adalah seni berbicara. Asalnya digunakan pada perdebatan-perdebatan dalam ruang sidang pengadilan untuk saling memengaruhi sehingga bersifat antarpersona. Retorika berkembang menjadi sejenis kegiatan komunikasi massa (pidato di hadapan khalayak), dan Aristoteles membagi retorika menjadi tiga: deliberatif, forensik, dan demonstratif.

b. Agitasi Politik

Berasal dari kata agitare yang artinya ialah bergerak atau menggerakkan. Menurut Blumer (dalam Shahreza \& El-Yana, 2016), tujuan dari agitasi adalah untuk membangkitkan rakyat pada gerakan politik, disampaikan secara lisan atau tulisan dengan merangsang dan 
membangkitkan emosi massa. Agitasi dimulai dengan cara membuat kontradiksi di masyarakat serta menggerakan khalayak agar menentang kenyataan hidup yang dialami (penuh ketidakpastian atau penuh penderitaan) untuk menimbulkan kegelisahan di kalangan massa. Orang yang melakukan agitasi disebut 'agitator', yaitu orang yang berupaya menimbulkan ketidakpuasan, kegelisahan atau pemberontakan. Ada agitator yang sikapnya selalu gelisah dan agresif, namun ada juga yang tenang dan cenderung pendiam tapi dapat menggerakkan massa khalayak dengan ucapan dan tulisannya.

c. Propaganda

Berasal dari bahasa Latin propagare (menanamkan tunas suatu tanaman) yang pada awalnya adalah sebentuk kegiatan penyebaran Katolik pada 1822. Paus Gregorius XV membentuk sebuah komisi kardinal (Congregatio de Propaganda Fide) untuk menumbuhkan keimanan kristiani di antara bangsa-bangsa di dunia ini. Propagandis adalah orang yang melakukan propaganda, mampu menjangkau khalayak yang lebih besar. Propaganda biasanya dilakukan politisi atau kader partai politik yang mampu menggiring pemikiran khalayak.

d. Public Relations (PR) Politics

Kehadiran PR Politik mengalami pertumbuhan pesat di Amerika Serikat setelah PD II, sebagai sebuah upaya alternatif mengimbangi propaganda yang dianggap mampu mengancam kehidupan sosial-politik. Presiden Roosevelt (1945) mendeklarasikan pemerintahan yang jujur sekaligus terbuka dalam menjalin hubungan dengan rakyat; tujuan utamanya untuk menciptakan hubungan saling percaya, harmonis, terbuka atau akomodatif di antara politisi, kaum profesional, serta aktivis dengan khalayak (masyarakat).

e. Kampanye Politik

Kampanye politik merupakan bentuk komunikasi politik yang dilakukan orang atau kelompok (organisasi) pada waktu tertentu untuk meraih dan memperkuat dukungan politik dari rakyat/pemilih. Kampanye politik adalah rangkaian tindakan komunikasi yang terencana dengan tujuan menciptakan efek tertentu pada khalayak, dilakukan secara berkelanjutan pada kurun waktu yang tertentu. Berbeda dengan propaganda, kampanye memiliki ciri-ciri: sumbernya jelas, waktu pelaksanaan terikat sekaligus dibatasi, gagasan yang dihadirkan bersifat terbuka diperdebatkan, tujuannya tegas, variatif dan spesifik, modus penerimaan pesan persuasif, modus tindakannya diatur kaidah dan kode etik, mempertimbangkan kepentingan kedua belah pihak. 
f. Lobi Politik

Kata lobi bermakna tempat para tamu menunggu untuk berbincang-bincang di hotel, dan yang hadir adalah para politisi yang melakukan pembicaraan politik (political lobbying) di mana terjadi dialog tatap muka secara informal tetapi penting. Dari lobi itu biasanya muncul kesepahaman dan kesepakatan bersama yang diperkuat melalui pembicaraan formal dalam rapat/sidang politik yang akan menghasilkan keputusan dan sikap politik tertentu.

g. Media Massa

Menurut McLuhan, media massa adalah perluasan dari pancaindra manusia (sense extention theory) dan media pesan (medium is the message), yang dalam konteks ini adalah pesan politik; tujuannya adalah untuk mendapatkan pengaruh, kekuasaan-otoritas, membentuk dan mengubah opini publik atau mendapatkan dukungan serta citra politik dari khalayak yang lebih luas atau yang tidak dapat dijangkau bentuk komunikasi lainnya.

\section{Pesan Nonverbal dalam Komunikasi Politik}

Komunikasi politik nonverbal merupakan tindakan dalam peristiwa komunikasi politik yang dapat saja ditafsirkan secara berbeda oleh khalayak. Karena itulah, tindakan harus diamati dari waktu ke waktu agar dapat ditemukan polanya. Jika pesan nonverbal itu berulangulang, terbentuk satu pola tindakan. Pola itu selanjutnya menjadi pedoman untuk melakukan suatu prediksi pada masa depan. Artinya, dilakukan berdasarkan pola. Apabila suatu saat terjadi tindakan di luar pola (misalnya, politisi di Senayan semuanya tak berpakaian sipil lengkap) maka terjadilah kejutan (Arifin, 2011).

Komunikasi nonverbal dijalani oleh individu atau lebih sewaktu menyampaikan isyaratisyarat nonverbal yang memiliki potensi untuk merangsang makna dalam pikiran individu atau individu-individu yang lain. Istilah nonverbal biasanya digunakan untuk melukiskan seluruh peristiwa komunikasi di luar kata-kata terucap dan tertulis meskipun tidak ada kesepakatan tentang proses nonverbal ini, kebanyakan ahli setuju apabila hal-hal seperti ekspresi wajah, pandangan mata, postur, gerakan tubuh, sentuhan, pakaian, artefak, diam, ruang, waktu, dan suara (Porter \& Samovar, 2010).

Komunikasi nonverbal juga bisa diartikan suatu penciptaan dan pertukaran pesan dengan tidak menggunakan kata-kata, tetapi menggunakan gerakan tubuh, sikap tubuh, intonasi nada (tinggi-rendahnya nada), kontak mata, ekspresi muka, kedekatan jarak dan sentuhansentuhan. Dapat juga dikatakan bahwa komunikasi nonverbal adalah seluruh kejadian di sekeliling situasi komunikasi yang tak terkait dengan kata-kata yang ditulis atau diucapkan 
dan mencakup semua stimulus nonverbal yang pada setting komunikatif digeneralisasikan individu dan lingkungan individu yang memakainya (Liliweri, 2007).

Hal yang menarik dari pesan nonverbal ini adalah studi yang dilakukan Albert Mehrabian (dalam Cangara, 2009) yang menyimpulkan bahwa tingkat kepercayaan orang hanya $7 \%$ berasal dari bahasa verbal, $38 \%$ dari vokal suara dan 55\% dari ekspresi muka. la juga menambahkan jika terjadi pertentangan antara apa yang diucapkan oleh seseorang dengan perbuatannya maka orang cenderung lebih mempercayai hal-hal yang bersifat nonverbal.

\section{Jenis-Jenis Pesan Nonverbal}

Berkaitan dengan komunikasi politik, ada lima klasifikasi pesan nonverbal yang dapat digunakan (Rakhmat, 2003), yaitu pesan kinesik, proksemik, artifaktual, paralinguistik, dan sentuhan. Sementara itu, Cangara (2009) mengelompokkan pesan nonverbal menjadi sepuluh 10 bentuk sebagaimana berikut ini.

a. Pesan Kinesik (Kinesics)

Kinesik merupakan simbol nonverbal yang ditunjukkan oleh gerakan-gerakan tubuh. Misalnya emblems adalah isyarat yang memiliki arti langsung terhadap simbol yang dibuat gerakan badan. Mengangkat jari telunjuk serta jari tengah, yang membentuk huruf $\checkmark$ yang sering dilakukan tokoh perjuangan Palestina Yaser Arafat mempunyai arti victory atau kemenangan.

b. Pesan Sentuhan (Touching)

Sentuhan adalah isyarat yang dilambangkan dengan sentuhan badan, seperti berjabat tangan, saling rangkul, dan menepuk pundak supaya bisa bertambah akrab satu sama lain.

c. Intonasi Suara (Paralanguage)

Intonasi adalah isyarat yang ditimbulkan oleh tekanan atau irama suara. Pada suatu ekspresimen yang dilakukan di Jurusan IImu Komunikasi Northwestern University (AS) ditampilkan dua orang pembicara yang berbeda tapi dengan materi yang sama. Ternyata ekspresimen itu menghasilkan kesimpulan adanya pembicara yang dapat memikat pendengar lantaran faktor artikulasi pengucapan kata yang baik serta suara menggelegar, sementara pembicara yang satunya kurang dapat memikat pendengar sebagaimana pembicara pertama. Karena itu, seorang kandidat/juru kampanye perlu sedapat mungkin punya suara yang berwibawa. 


\section{d. Gerakan Mata (Eye Gaze)}

Mata ialah alat komunikasi yang paling mengandung makna dalam memberi isyarat tanpa kata. Ungkapan pandangan pertama mempunyai makna yang ditimbulkan oleh karena gerakan mata. Dalam berbagai studi yang dilakukan pakar psikologi tentang gerakan mata, disimpulkan bahwa jika seseorang tertarik pada sebuah objek tertentu, pandangannya akan terarah ke objek tersebut tanpa terputus pada waktu yang relatif lama dengan bola mata cenderung menjadi besar.

e. Diam (Silent)

Berbeda dengan tekanan suara maka sikap diam pun sebagai simbol nonverbal yang memiliki makna. Max Picard menyatakan bahwa diam tidak selamanya mempunyai arti negatif, tetapi bisa juga melambangkan sikap positif. Banyak orang mengambil sikap diam lantaran tidak mau menyatakan sesuatu hal yang menyakitkan orang lain, misalnya berkata "tidak".

\section{f. Postur Tubuh}

Orang lahir ditakdirkan dengan berbagai jenis bentuk tubuh. Well dan Siegel (1961), dua pakar psikologi melalui studi yang mereka lakukan, berhasil menggambarkan bentuk tubuh manusia dengan karakternya. Kedua pakar ini membagi bentuk tubuh manusia menjadi tiga tipe, yaitu ectomorphy bagi orang yang memiliki tubuh kurus tinggi, mesomorphy bagi mereka yang mempunyai bentuk tubuh tegap, tinggi serta atletis, dan terakhir endomorphy untuk mereka yang memiliki tubuh pendek, bulat dan gemuk.

g. Artifak dan Visualisasi

Seni juga banyak memberi isyarat yang mengandung makna. Para antropolog dan arkeolog telah lama memberi perhatian pada benda-benda yang digunakan manusia dalam hidupnya, seperti artifacts, yaitu hasil kerajinan manusia (seni) baik itu yang melekat pada diri manusia atau yang ditujukan kepada kepentingan umum. Artifacts selain mengandung estetika, untuk menunjukkan status atau identitas diri seseorang atau suatu bangsa. Contoh: baju, seragam, topi, cincin, gelang, alat transportasi, alat rumah tangga, arsitektur, monumen, dan lain sebagainya. Benda artifak juga banyak digunakan dalam kampanye politik dengan berbagai macam bentuk, misalnya topi, baret, jaket seragam, pin, dasi, dan alat-alat musik seperti gendang dan pakaian adat.

h. Warna

Warna juga memberikan arti terhadap suatu objek. Di Indonesia, warna hijau sering diidentikkan dengan warnai Partai Persatuan Pembangunan, kuning sebagai warna Partai Golongan Karya, merah sebagai warna Partai Demokrasi Indonesia, dan lain sebagainya. 
i. Waktu

Waktu bagi masyarakat awam sering kali dikaitkan pada kepercayaan mereka, tetapi bagi orang berpendidikan tinggi, waktu dilihat dari perpektif musim, seperti musim kemarau dan hujan yang amat memengaruhi aktivitas mereka. Kegiatan kampanye misalnya bisa saja tidak efektif lantaran musim, atau ada peristiwa-peristiwa penting yang lebih menarik perhatian masyarakat daripada kampanye partai.

j. Logo

Logo adalah tanda, lambang, atau lencana yang digunakan organisasi, perusahaan, atau partai. Logo menjadi sebuah simbol pesan yang multimakna mulai dari filosofi, visi, misi serta tujuan organisasi/lembaga. Selain memiliki bendera sebagai simbol-simbol partai, hampir semua partai politik juga memiliki logo.

k. Bunyi-bunyian

Hampir semua etnis punya simbol-simbol bunyi, yang diintegrasikan menjadi irama musik atau kesenian. Misalnya suling, tambur, peluit, tepompet dan lain sebagainya. Partaipartai politik juga menggunakan alat komunikasi nonverbal seperti ini, antara lain untuk memupuk semangat kebersamaan, dan juga sebagai perang urat saraf bagi lawan partai dalam berkompetisi merebut suara pemilih.

\section{METODE PENELITIAN}

Penelitian ini adalah penelitian deskriptif kualitatif. Unit analisis pada penelitian ini ialah bentuk-bentuk pesan nonverbal dalam komunikasi politik Wahidin Halim pada Pilkada Banten 2017, yang terdiri dari pesan kinesik (pesan fasial dan gestural), pesan proksemik, pesan artifaktual, dan pesan paralinguistik. Teknik pengumpulan data yang digunakan dalam penelitian ini adalah wawancara mendalam, observasi nonpartisipatif, studi pustaka dan studi dokumentasi. Teknik analisis data pada penelitian ini mengambil model Miles \& Huberman yang terdiri dari: reduksi data, penyajian data, dan verifikasi. Adapun teknik keabsahan data yang digunakan adalah triangulasi sumber data.

\section{HASIL DAN PEMBAHASAN}

Dalam bagian ini akan dibahas berbagai bentuk pesan nonverbal yang digunakan Wahidin Halim dalam masa kampanye Pilkada Banten 2017, yang terdiri dari: (1) pesan kinesik; (2) proksemik; (3) artifaktual; dan (4) paralinguistik. 


\section{Pesan Kinesik (Facial dan Hand Gesture)}

Pada konteks politik, politisi sering dianggap sebagai orang yang terampil dalam hal mengendalikan ekspresi wajah. Dalam suatu peristiwa, meskipun mereka dinyatakan bersalah oleh pengadilan karena sudah terbukti melakukan korupsi, pada kennyataannya mereka mampu tampil tenang dan penuh percaya diri di hadapan publik, meskipun bisa saja mereka akan menangis penuh penyesalan ketika telah dijebloskan ke dalam penjara.

Selama masa kampanye Pilkada Banten 2017 masyarakat Banten tentunya sering menemukan baliho dan spanduk yang memuat wajah Wahidin Halim sedang tersenyum, atau ketika sedang kampanye terbuka atau mengikuti program debat kandidat di televisi. Bagi sebagian masyarakat Banten yang sudah mengenal sosok Wahidin Halim, ekspresi senyum Wahidin Halim tentunya bukan hal aneh, karena memang sudah melekat dalam keseharian Wahidin Halim. Tapi, bagi masyarakat yang belum mengenal sosok Wahidin Halim, mereka dapat saja mengira jika senyum tersebut bersifat artifisial atau by design, yang dirancang khusus pada masa kampanye politik.

Bagi sebagian besar masyarakat Kota Tangerang Wahidin Halim dikenal sebagai figur yang dekat dengan masyarakat dan murah senyum, selain juga sebagai sosok yang tegas dan tidak kenal kompromi. Kedekatan tersebut tentu bukan isapan jempol semata, atau bukan juga bagian dari pencitraan, karena bisa dibuktikan dengan selalu dibukanya pintu rumah Wahidin Halim kepada siapa pun yang hendak menyampaikan aspirasinya. Jika pintu rumah selalu dibuka untuk masyarakat maka orang itu (Wahidin Halim) harus rela kehilangan privasinya demi mengurusi aneka persoalan masyarakat dan mencarikan solusinya. Dalam keadaan seperti ini, senyum mutlak dibutuhkan agar masyarakat yang datang mengadukan persoalannya merasa diterima dan nyaman sewaktu menyampaikan aspirasi/persoalan yang dialaminya.

Dalam konteks Pilkada Banten 2017, meskipun Wahidin Halim diserang dengan isu dinasti politik dan korupsi yang menyebar secara masif, Wahidin Halim bisa disebut mampu menghadapinya secara arif dan bijaksana. Sebab itu, wajahnya selalu tersenyum tatkala sedang berkampanye menemui masyarakat Banten. Dalam konteks ini, Leathers (dalam Rakhmat, 2003) mengemukakan penelitian-penelitian tentang ekspresi wajah yang salah satunya ialah guna mengkomunikasikan tingkat pengendalian individu terhadap pernyataannya sendiri, terutama yang menyangkut pernyataan bahwa Wahidin Halim memang tidak sedang terlibat korupsi atau sedang melanggengkan dinasti politik, terutama karena memutuskan untuk memilih Andika Hazrumy sebagai pendampingnya. 
Bahkan ada yang menarik dari ucapan Wahidin Halim menyangkut hal ini ketika ia memutuskan untuk berpasangan dengan Andika Hazrumy, terlepas dari adanya suatu anggapan bahwa langkah tersebut adalah strategi semata untuk memenangkan Pilkada Banten 2017: "Saya kira tidaklah perlu beranggapan jika dosa yang dilakukan ibunya akan turun kepadanya. Saya sangat yakin Andika bertekad untuk membuktikan kepada masyarakat bahwa ia tidak akan mengulangi apa yang dilakukan ibunya, dan karena itu saya patut memberi kesempatan, dan saya juga akan membimbing Andika agar bisa lebih baik, khususnya bagaimana cara menjalani pemerintahan yang baik dan benar." (Wawancara dengan Ahmad Jazuli Abdillah, 30 Juli 2018)

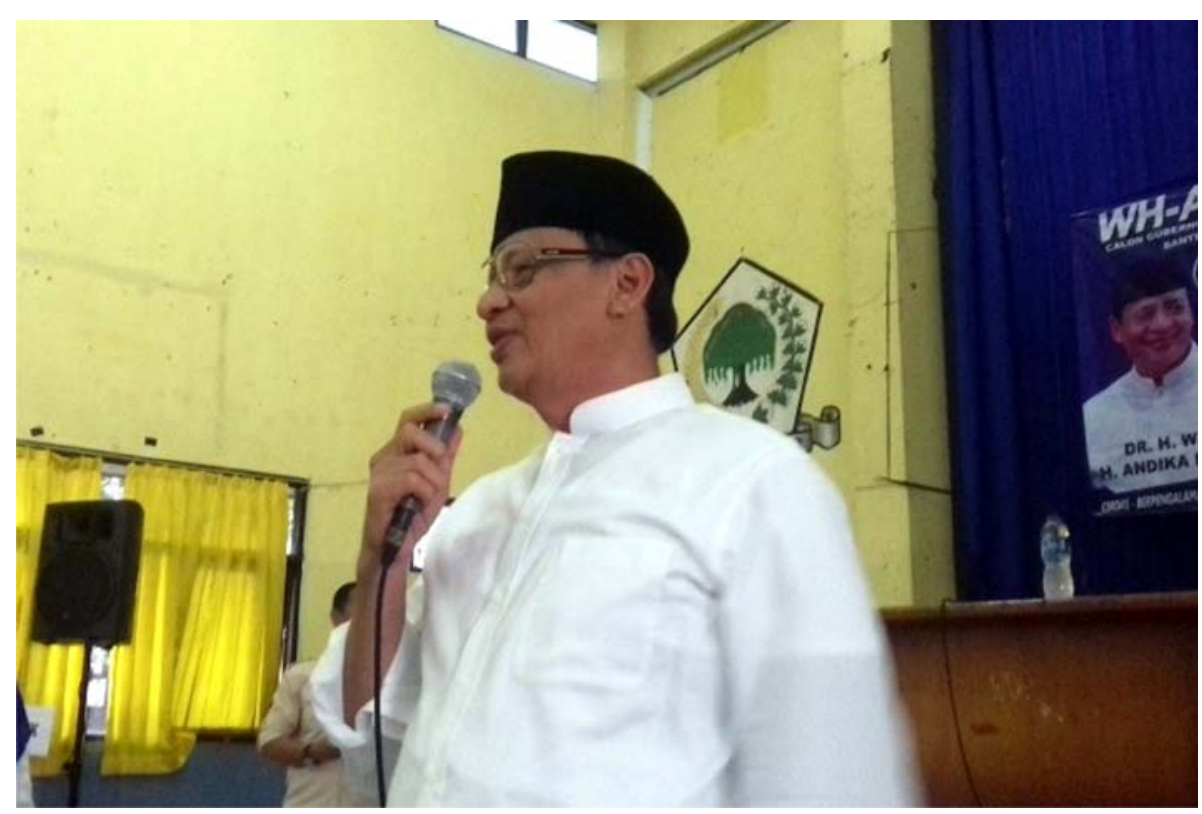

Gambar 1. Senyum Khas Wahidin Halim Ketika sedang Berkampanye di Hadapan Guru TK seKota Tangerang

(Sumber: www.bidikbanten.com)

Selain ekspresi wajah, ekspresi lainnya yang tak kalah pentingnya dalam proses komunikasi politik ialah gerakan tubuh atau pesan gestural. Pesan gestural berperan penting memperkuat pesan verbal yang diucapkan politisi ketika kampanye. Bagaimana mungkin seorang politisi dikatakan punya kepercayaan diri yang tinggi sementara ketika berkampanye ia hanya sekadar berdiri kaku dan terpaku pada microfon atau teks pidato.

Ketika kampanye di hadapan masyarakat, terutama ketika memberikan informasi yang terkait dengan program kerja dan rencana-rencana yang ingin diwujudkan apabila terpilih menjadi gubernur Banten, olah tangan (hand gesture) yang sering diperlihatkan oleh Wahidin 
Halim adalah mengangkat tangan kanan dengan jari terbuka. Olah tangan (hand gesture) ini memperlihatkan Wahidin Halim menguasai materi yang disampaikan sekaligus menguasai audiens yang ada di hadapannya.

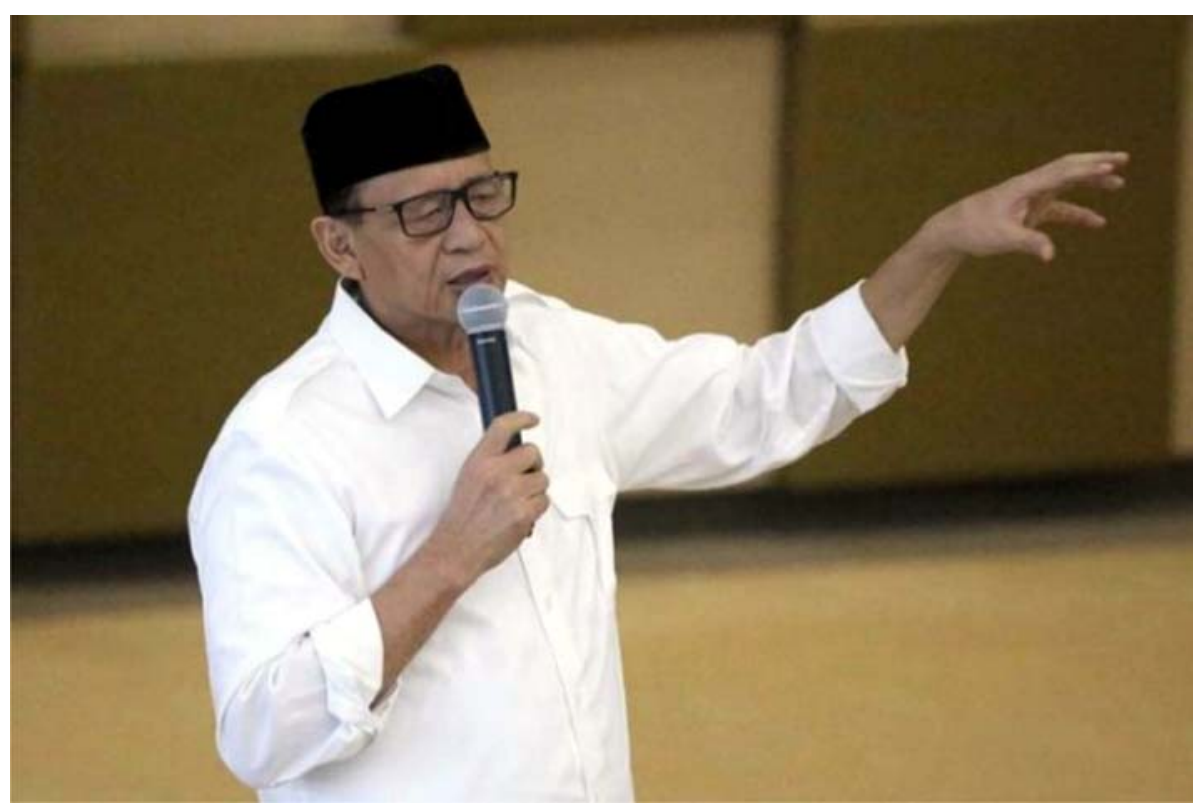

Gambar 2. Hand Gesture Wahidin Halim Ketika Memberi Penjelasan kepada Audiensnya (Sumber: www.rilitas.com)

\section{Pesan Proksemik}

Dalam kontestasi pemilu atau pilkada, setiap kandidat atau calon tentu saja akan berlomba-lomba mendekati rakyat (konstituen) sembari menawarkan apa yang disebut program kerja (pesan politik). Kemampuan dalam hal membangun hubungan yang lebih emosional (meminimalisir jarak semaksimal mungkin) dapat menjadi peluang tersendiri bagi politisi dalam meraih simpati dari masyarakat, khususnya masyarakat akar rumput.

Sebagai sosok yang sudah berpengalaman di dunia politik, dan dengan segudang prestasi sewaktu menjabat sebagai Wali Kota Tangerang, Wahidin Halim sudah terbiasa mendekati serta menyapa khalayak/masyarakat dari kalangan atas hingga bawah. Hal ini juga menjadi kelebihan/modal politik tersendiri yang akhir-akhir ini jarang ditunjukkan para politisi. Pada konteks membangun kedekatan dengan masyarakat, maka pesan atau komunikasi nonverbal sangatlah berperan penting untuk menumbuhkan suatu kedekatan emosional yang tulus dan tidak hanya pencitraan semata. Artinya, dibutuhkan kedekatan jarak yang bernuansa emosional antara kandidat dengan konstituennya. 
Pada masa kampanye Pilkada Banten 2017, modal kedekatan dengan masyarakat tersebut masih diperlihatkan Wahidin Halim di berbagai kesempatan, khususnya tatkala menyapa masyarakat kelas bawah. Artinya, Wahidin Halim telah "meruntuhkan" jarak antara calon pemimpin dengan rakyatnya, bahwa "pemimpin harus berani dekat dengan dengan rakyatnya dan ada di tengah-tengah mereka untuk mengayomi."

Menurut kategori berdasarkan penjelasaan Edward T. Hall (dalam Danesi, 2011), maka jarak yang cenderung terbangun saat Wahidin Halim sedang kampanye

tergolong sebagai jarak intim dan jarak personal. Pada jarak intim ( 0 inci-18 inci) semua indera diaktifkan dan kehadiran orang lain tak bisa diabaikan. Fase dekat (0 inci-6 inci) merupakan zona penuh emosi untuk menghibur atau melindungi, sementara fase jauh (6 inci-18 inci) adalah jarak di mana anggota keluarga yang dekat/teman akrab berinteraksi satu sama lain.

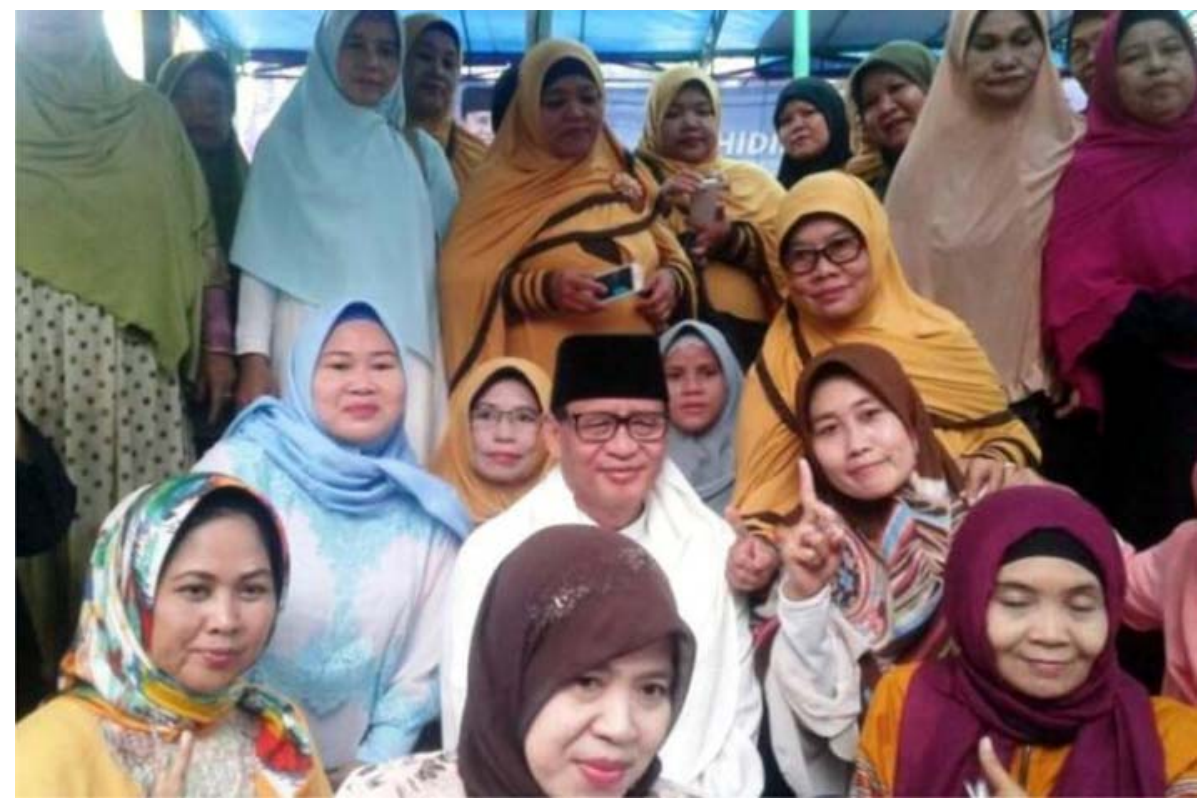

Gambar 3. Wahidin Halim Berfoto-Ria bersama Ibu-Ibu Pengajian di Pamulang, Kota Tangerang Selatan

(Sumber: www.progresnews.com)

\section{Pesan Artifaktual}

Sebagai calon pemimpin setiap kandidat tentu akan memperhatikan dengan teliti penampilannya yang sebagian besar ditentukan oleh jenis pakaian yang dipilihnya mulai dari baju putih dipadu dengan jas, batik, sampai dengan baju koko atau baju kotak-kotak yang menjadi pakaian ciri khas Jokowi-Ahok pada Pilkada DKI Jakarta 2012. 
Pada masa kampanye Pilkada Banten 2017, sosok Wahidin Halim ternyata kerap mengenakan baju koko putih, celana hitam, dan peci hitam. Pakaian tersebut senantiasa dikenakan oleh Wahidin Halim ketika menemui berbagai unsur masyarakat dalam masa kampanye. Artinya, pakaian seperti batik, kemeja putih atau jas jarang dikenakan, hanya pada saat tertentu.

Uniknya lagi, foto Wahidin Halim sebagaimana terlihat dalam kertas suara, yang juga mengenakan baju koko putih dan peci hitam, bukan foto khusus yang disiapkan tim sukses, konsultan kampanye, atau fotografer profesional (by design), melainkan dipilih sendiri oleh Wahidin Halim dari foto-foto yang ada, "Malahan saran dari tiga sampai empat konsultan media yang ngerancang fotonya ngga dipake karena WH seneng sama foto yang itu, pake baju koko putih dan peci hitam." (Wawancara dengan Ahmad Jazuli Abdillah, 30 Juli 2018)

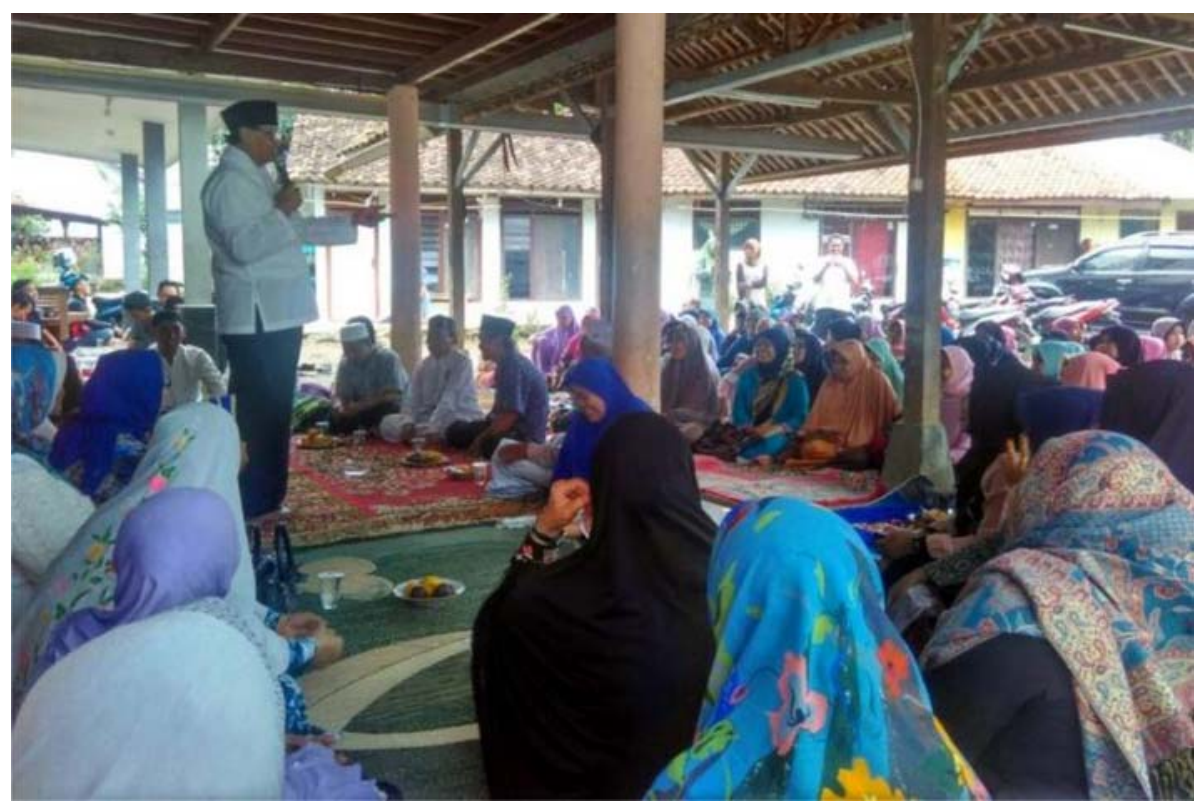

Gambar 4. Wahidin Halim Mengenakan Pakaian Ciri Khasnya (Baju Koko Putih, Peci Hitam dan Celana Hitam)

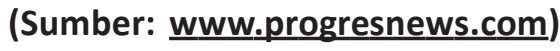

\section{Pesan Paralinguistik}

Pada masa kampanye Pilkada Banten 2017 Wahidin Halim, gaya bicara Wahidin Halim yang cenderung cepat dan enggan berpedoman pada teks, memperlihatkan bahwa Wahidin Halim merupakan pribadi yang cerdas serta menguasai permasalahan. Artinya, Wahidin Halim dapat mengelola waktu yang tersedia saat berpidato, dan hal ini menjadi kelebihan tersendiri karena bisa mengarah kepada komunikasi dua arah antara Wahidin Halim (sebagai 
komunikator) dengan masyarakat sebagai audiensnya. Menurut Ahmad Jazuli Abdillah (Wawancara tanggal 30 Juli 2018) hal itu merupakan kelebihan Wahidin Halim, karena dengan cara tersebut apa yang disampaikan cenderung berisi atau bernas, hal yang belum tentu keluar jika menggunakan teks/naskah pidato.

Sementara itu, sebagai orang Betawi, intonasi suara Wahidin Halim pada waktu berbincang-bincang dengan masyarakat Banten cenderung bersemangat, menandai suatu keyakinan bahwa hal yang disampaikannya memang benar adanya dan tidak dibuat-buat (rekayasa). Selain itu, gaya komunikasi Wahidin Halim yang cenderung apa adanya atau ceplas-ceplos dan suka menyelipkan joke-joke ketika sedang berkomunikasi baik formal maupun informal, ternyata selaras dengan budaya masyarakat Banten yang suka humor (Tihami, 2012). Hal ini pun menjadi kelebihan yang dimiliki Wahidin Halim, khususnya untuk mengimbangi lawan politiknya Rano Karno, yang dikenal sebagai artis/komedian. Dengan demikian, selain tegas dan cerdas, Wahidin Halim juga merupakan pribadi yang apa adanya dan humoris yang bisa membuat suasana komunikasi menjadi lebih mencair dan mengalir.

Tabel 1. Pesan Nonverbal dalam Komunikasi Politik Wahidin Halim pada Pilkada Banten 2017

\begin{tabular}{|c|c|c|c|c|}
\hline No & $\begin{array}{r}\text { Jenis Pesan } \\
\text { Nonverbal }\end{array}$ & Kategori & $\begin{array}{c}\text { Temuan } \\
\text { Penelitian }\end{array}$ & Makna \\
\hline \multirow[t]{2}{*}{1} & Kinesik & $\begin{array}{l}\text { Pesan Fasial } \\
\text { (Ekspresi Wajah) }\end{array}$ & Murah Senyum & $\begin{array}{l}\text { Menunjukkan sikap dan } \\
\text { kepribadian yang bersahaja } \\
\text { sekaligus menjadi indikasi } \\
\text { suatu pengendalian diri jika } \\
\text { dirinya tidak sedang berupaya } \\
\text { membangun dinasti politik } \\
\text { (dengan memilih Andika } \\
\text { Hazrumy sebagai } \\
\text { pendampingnya) atau sedang } \\
\text { terlibat kasus korupsi. }\end{array}$ \\
\hline & & $\begin{array}{l}\text { Pesan Gestural } \\
\text { (Olah Tangan } \\
\text { atau Hand } \\
\text { Gestural) }\end{array}$ & $\begin{array}{l}\text { Mengangkat } \\
\text { Tangan dengan } \\
\text { Jari-jemari } \\
\text { Terbuka }\end{array}$ & $\begin{array}{l}\text { Berusaha meyakinkan } \\
\text { masyarakat Banten bahwa } \\
\text { dirinya adalah pribadi cerdas } \\
\text { yang mampu memberikan } \\
\text { solusi bagi berbagai persoalan } \\
\text { yang sedang dihadapi } \\
\text { masyarakat Banten. }\end{array}$ \\
\hline 2 & Proksemik & $\begin{array}{l}\text { Pengaturan } \\
\text { Jarak }\end{array}$ & $\begin{array}{l}\text { Jarak Intim dan } \\
\text { Jarak Personal }\end{array}$ & $\begin{array}{l}\text { Sebagai simbol calon } \\
\text { pemimpin yang merakyat dan } \\
\text { selalu siap mendengarkan } \\
\text { aspirasi masyarakat Banten. }\end{array}$ \\
\hline
\end{tabular}




\begin{tabular}{|c|c|c|c|c|}
\hline 3 & Artifaktual & Penampilan & $\begin{array}{l}\text { Baju Koko } \\
\text { Putih, Celana } \\
\text { Hitam, dan Peci } \\
\text { Hitam }\end{array}$ & $\begin{array}{l}\text { Simbol pribadi yang } \\
\text { sederhana, selalu dekat } \\
\text { dengan rakyat, dan selaras } \\
\text { dengan masyarakat Banten } \\
\text { yang dikenal sebagai } \\
\text { masyarakat agamis. }\end{array}$ \\
\hline \multirow[t]{3}{*}{4} & Paralinguistik & $\begin{array}{l}\text { Kecepatan } \\
\text { Berbicara }\end{array}$ & Cepat & $\begin{array}{l}\text { Sebagai pribadi yang cerdas, } \\
\text { karena mampu menguasai } \\
\text { berbagai persoalan yang } \\
\text { dihadapi masyarakat Banten } \\
\text { sekaligus mencarikan } \\
\text { solusinya. }\end{array}$ \\
\hline & & Intonasi Suara & Bersemangat & $\begin{array}{l}\text { Optimisme membawa Propins } \\
\text { Banten ke arah yang lebih } \\
\text { baik. }\end{array}$ \\
\hline & & Gaya Berbicara & $\begin{array}{l}\text { Ceplas-Ceplos } \\
\text { dan Senang } \\
\text { Humor }\end{array}$ & $\begin{array}{l}\text { Menunjukkan sikap dan } \\
\text { kepribadian yang bersahaja } \\
\text { sekaligus terkesan jauh dari } \\
\text { formalitas. Jadi, rakyat Banten } \\
\text { bisa dengan mudah } \\
\text { menyampaikan aspirasinya. }\end{array}$ \\
\hline
\end{tabular}

\section{KESIMPULAN}

Selama menjalani kampanye Pilkada Banten 2017, ekspresi wajah yang selalu diperlihatkan Wahidin Halim adalah tersenyum, sementara gerakan olah tangan (hand gesture) yang sering diperlihatkan adalah mengangkat tangan kanan dengan jari terbuka, memperlihatkan dirinya menguasai materi yang disampaikan serta menguasai audiens di hadapannya. Ketika berada di tengah masyarakat, jarak yang terbangun antara Wahidin Halim dengan masyarakat Banten tergolong sebagai jarak intim serta personal, di mana kedekatan emosional antara Wahidin Halim dan masyarakat Banten dapat lebih mudah terbangun. Selain itu, masyarakat dapat mempersepsikan Wahidin Halim sebagai sosok yang merakyat dan dekat dengan rakyatnya. Sementara penampilan (pesan artifaktual) yang menjadi ciri khasnya ialah baju koko putih, celana hitam, dan peci hitam. Adapun gaya berbicara Wahidin Halim cenderung cepat dan tidak berpedoman pada teks/naskah pidato, mengindikasikan bahwa dirinya adalah pribadi yang cerdas sekaligus menguasai persoalan yang sedang disampaikannya. Hal ini juga didukung intonasi suaranya yang bersemangat dan gaya bicaranya yang ceplas-ceplos dan selalu menyelipkan humor baik dalam suasana formal maupun informal. 


\section{REFERENSI}

Agustino, Leo. (2010). “Dinasti Politik Pasca-Otonomi Orde Baru: Pengalaman Banten". Prisma, 29(3): 102-116.

Agustino, Leo. (2011). “Pemilihan Gubernur Pasca Orde Baru: Pengalaman Provinsi Banten pada Tahun 2001 dan 2006". Jurnal Edita, 2(1): 1-45.

Arifin, Anwar. (2011). Komunikasi Politik: Filsafat-Paradigma-Teori-Tujuan Strategi dan Komunikasi Politik Indonesia. Yogyakarta: Graha Ilmu.

Azmi, Khaerul. (2017). "Pengelolaan Kesan Calon Gubernur Banten "Wahidin Halim” pada Media Online Twitter dan Facebook". Communication, 8(2): 64-87.

Cangara, Hafied. (2016). Komunikasi Politik: Konsep, Teori, dan Strategi. Jakarta: Rajawali Pers.

Christiawan, William. (2016). "Analisa Kasus Korupsi Pengadaan Alat Kesehatan di Provinsi Banten dan Kota Tangerang Selatan". Jurnal Akuntansi Bisnis, 14(28): 131-148.

Danesi, Marcel. (2011). Pesan, Tanda, dan Makna. Yogyakarta: Jalasutera.

Fatanti, Megasari N. dan I Wayan Suyadnya. (2017). "Olah Tubuh Politisi dalam Bingkai Media: Analisis Komunikasi Non Verbal Surya Paloh dalam Membangun Citra Politik". Jurnal Komunikasi Indonesia, 5(1): 26-37.

Fauzanafi, Muhammad Zamzam. (2016). "Searching for Digital Citizenship: Fighting Corruption in Banten, Indonesia". ASEAS (Austrian Journal of South-East Asian Studies), 9(2): 289-294.

Hakim, Setiawandi (et al.). (2017). "The Effort of Corruption Prevention through the Alteration of Organization Culture: Studies in Banten Provincial Government". International Journal of Management and Administrative Sciences (IJMAS), 4(12): 76-83.

Hamid, Abdul. (2014). "A Family Matter: Political Corruption in Banten, Indonesia". Asian Politics \& Policy, 6(4): 577-593.

Hikmat, Mahi M. (2010). Komunikasi Politik: Teori dan Praktik (dalam Pilkada Langsung). Bandung: Simbiosa Rekatama Media.

Humaeni, Ayatullah. (2015). "Ritual, Kepercayaan Lokal dan Identitas Budaya Masyarakat Ciomas Banten". el Harakah, 17(2): 157-181.

Istiyanto, S. Bekti. (2010). "Pentingnya Komunikasi Artifaktual dalam Keberhasilan Modifikasi Komunikasi Antarmanusia”. Acta diurnA, 6(2): 12-22.

Jalan Buntu Kampanye Gubernur Banten Berobat Gratis Modal KTP. (6 Maret 2018). Diakses dari: https://rilitas.com/06/03/2018/jalan-buntu-kampanye-gubernur-banten-berobatgratis-modal-ktp/ 
Kampanye Cagub WH Dihadapan Guru TK Janji Naikan Uang Insentif. Diakses dari: http:// www.bidikbanten.com/2016/11/kampanye-cagub-wh-dihadapan-guru-tk-janji-naikanuang-insentif/

Kunjungi Tangsel, Wahidin Halim Siap Kembangkan Wisata Religi Di Banten. (15 Desember 2016). Diakses dari: http://progresnews.com/politik/kunjungi-tangsel-wahidin-halim-siapkembangkan-wisata-religi-di-banten/

Kusumaningtyas, Atika Nur. (2017). "Perempuan Kepala Daerah dalam Jejaring Oligarki Lokal”. Jurnal Penelitian Politik, 14(2): 239-260.

Liliweri, Alo. (2007). Makna Budaya dalam Komunikasi Antar Budaya. Yogyakarta: LKiS.

Mariana, Dede dan Luthfi Hamzah Husin. (2017). “Democracy, Local Election, and Political Dynasty in Indonesian Politics". Jurnal Wacana Politik, 2(2): 88-97.

Masyarakat Pamulang Doakan Pasangan Wahidin Halim-Andika Pimpin Banten. (9 Februari 2017). Diakses dari: http://progresnews.com/politik/masyarakat-pamulang-doakanpasangan-wahidin-halim-andika-pimpin-banten/

McNair, Brian. (2003). An Introduction to Political Communication. New York: Routledge.

Nashrudin, Achmad. (2017). "Konstruksi Realitas Radar Banten pada Pemberitaan Pilkada Banten 2017". Nyimak Journal of Communication, 1(1): 49-77.

Nimmo, Dan. (2004). Komunikasi Politik: Komunikator, Pesan dan Media. Bandung: PT. Remaja Rosdakarya.

Nisa, Hoirun, Dwisetia Poerwono dan Firmansyah. (2017). "Corruption in Banten Province, Indonesia". Advanced Science Letters, 23(8): 7142-7145.

Porter, Richard E. dan Larry A. Samovar. (2010). "Suatu Pendekatan terhadap Komunikasi Antarbudaya". Dalam Deddy Mulyana dan Jalaluddin Rakhmat (eds.). Komunikasi Antarbudaya: Panduan Berkomunikasi dengan Orang-orang Berbeda Budaya. Bandung: PT. Remaja Rosdakarya.

Pratiwi, Bayu Nitin. (2017). "Analisis Gaya Komunikasi Ahmad Faiz Zainuddin”. eJournal Ilmu Komunikasi, 5(3): 376-387.

Rakhmat, Jalaluddin. (2003). Psikologi Komunikasi. Bandung: PT. Remaja Rosdakarya. Saragintan, Antonius dan Syahrul Hidayat. (2016). "Politik Pork Barrel di Indonesia: Kasus Hibah dan Bantuan Sosial di Provinsi Banten Tahun 2011". Jurnal Politik, 2(1): 137-164. Shahreza, Mirza dan Korry El-Yana. (2016). Etika Komunikasi Politik. Tangerang: Indigo Media.

Sitompul, Parulian. (2014). “Konstruksi Realitas Peran KPK dalam Pemberitaan Online Terkait Kasus Korupsi (Studi Framing Beberapa Pemberitaan Online Terkait Peran KPK pada Kasus Korupsi Mantan Gubernur Banten Ratu Atut Chosiah)". Jurnal Studi Komunikasi dan Media, 18(2): 169-182. 
Sutisna, Agus. (2015). “Jawara Banten: Local Strongman, Local Bossism dan Fenomena Uncivilitas". Jurnal IImu Komunikasi dan Pemerintahan, 2(2): 135-148.

Sutisna, Agus. (2017). “Gejala Proliferasi Dinasti Politik di Banten Era Kepemimpinan Gubernur Ratu Atut Chosiyah". Politik Indonesia (Indonesian Political Science Review), 2(2): 100120.

Tihami, M.A. (2012). “Dongeng Humor Islami di Pesantren Banten (Sebuah Tela'ah atas Makna Budaya dalam Dongeng Humor di Pesantren Banten)." Conference Proceedings: Annual International on Islamic Studies (AICIS XII).

Witantra, Ari Pandu dan Andin Nesia. (2000). "Pemuda dan Jawara dalam Politik Banten". Prosiding Magister Ilmu Komunikasi.

\section{Wawancara}

Abdillah, Ahmad Jazuli. (30 Juli 2018). Wawancara pribadi. 
